\title{
Extension Of The Periods For Consent To And Payment Of Quota Increases
}




\title{
INTERNATIONAL MONETARY FUND
}

July 2021

\section{EXTENSION OF THE PERIODS FOR CONSENT TO AND PAYMENT OF QUOTA INCREASES}

IMF staff regularly produces papers proposing new IMF policies, exploring options for reform, or reviewing existing IMF policies and operations. The following document(s) have been released and are included in this package:

- The Staff Report prepared by IMF staff and completed on June 10, 2021. The proposed decisions in the paper were approved by the Executive Board on June 18, 2021.

The IMF's transparency policy allows for the deletion of market-sensitive information and premature disclosure of the authorities' policy intentions in published staff reports and other documents.

Electronic copies of IMF Policy Papers are available to the public from http://www.imf.org/external/pp/ppindex.aspx

\author{
International Monetary Fund \\ Washington, D.C.
}




\title{
INTERNATIONAL MONETARY FUND
}

June 10, 2021

\section{EXTENSION OF THE PERIODS FOR CONSENT TO AND PAYMENT OF QUOTA INCREASES}

\author{
Approved By \\ Bernard Lauwers (FIN) \\ Prepared by the Finance Department \\ (in consultation with the Legal and Secretary's Departments).
}

1. This paper proposes a further extension, for one year, of the period for members to consent to an increase in their quotas under the Fourteenth General Review of Quotas (the Board of Governors' Resolution No. 66-2) ("Fourteenth Review") through June 30, 2022. ${ }^{1}$ The current deadline was last extended for a period of one year and is due to expire on June 30, 2021. ${ }^{2}$ However, Resolution No. 66-2 provides that the Executive Board may extend the period for consent as it may determine. An extension under Resolution No. 66-2 will also extend the period of consent for quota increases under the Eleventh General Review of Quotas (Resolution No. 53-2). ${ }^{3}$ As was done in June 2020, a one-year extension in the periods for consent is proposed in the wake of the still ongoing COVID-19 pandemic and is also consistent with broader streamlining efforts.

2. As of June 10, 2021, Eritrea and the Syrian Arab Republic had not yet consented to their proposed quota increases under Resolution No. 66-2. ${ }^{4}$ In addition, Sudan is currently not eligible to consent to its quota increase under the Eleventh and Fourteenth General Reviews due to protracted arrears to the Fund's General Resources Account. ${ }^{5,6} \mathrm{~A}$ separate workstream related to Sudan is currently ongoing. ${ }^{7}$

\footnotetext{
${ }^{1}$ See Board of Governors Resolution No. 66-2, Fourteenth General Review of Quotas and Reform of the Executive Board.

2 See Extension of the Periods for Consent to and Payment of Quota Increase (7/17/2020).

${ }^{3}$ See Paragraph 7 of the Board of Governors Resolution No. 66-2, Fourteenth General Review of Quotas and Reform of the Executive Board.

${ }^{4}$ Micronesia consented to and paid for its quota increase under the Fourteenth General Review of Quotas on November 25, 2020.

${ }^{5}$ Resolutions No. 53-2 and 66-2 provide that no member with overdue repurchases, charges, or assessments to the General Resources Account may consent to, or pay for, its quota increase until it becomes current with respect to these obligations.

${ }^{6}$ See Review of the Fund's Strategy on Overdue Financial Obligations (7/09/2018).

${ }^{7}$ In this context, in March 2021, the IMF and World Bank agreed that Sudan could be eligible for assistance under the Enhanced HIPC Initiative based on the preliminary assessment. This assessment is an important step towards forgiveness by all creditors of most of Sudan's total external debt, see Press Release No. 21/87. Subsequently, on May 10, the IMF Executive Board approved a financing plan that will help mobilize the resources needed for the IMF to cover its share of debt relief to Sudan, see Press Release No. 21/127.
} 
3. This paper also proposes an additional extension by one year of the periods for payment of quota increases under the Fourteenth Review, and for payment of quota increases under the 2008 Reform of Quota and Voice (the Board of Governors' Resolution No. 63-2) ("2008 Reform"), through June 30, 2022.

4. For the Fourteenth Review, under the Board of Governors Resolution No. 66-2, each member shall pay to the Fund the increase in its quota within 30 days after the later of (a) the date on which it notifies the Fund of its consent, or (b) the date on which all of the general effectiveness conditions for the quota increases under the Fourteenth Review are met, provided that the Executive Board may extend the payment period as it may determine. ${ }^{8}$ As of June 10,2021 , two members, namely Marshall Islands and Palau, while having consented to their Fourteenth Review quota increases, have not yet made their payments of their quota increases under Resolution No. 66-2. ${ }^{9}$ The Executive Board has previously extended the payment period several times, most recently through June 30, 2021. ${ }^{10}$ Staff continues to follow up on the remaining quota payments.

5. With respect to the 2008 Reform, among members that have consented to their ad hoc quota increases under the 2008 Reform, two members-Eritrea and the Syrian Arab Republic-require additional time to complete the payments for their ad hoc quota increases. The Executive Board has previously extended the payment deadline for these countries, most recently to June $30,2021 .{ }^{11}$

6. While it is important to emphasize that all members who have not yet consented to their Fourteenth Review quota increases should do so without further delay, and that members who have consented to their quota increases should make their quota payments in a timely manner, a further extension by one-year in the periods for consent to and payment of quota increases would seem appropriate.

7. In these circumstances, it is proposed to extend the period for consent under Resolution No. 66-2 to end at 6:00 p.m., Washington D.C. time, on June 30, 2022. It is also proposed that the Executive Board extend the period for payment of the quota increases under the Fourteenth General Review of Quotas through June 30, 2022 for those members whose quota payments would otherwise be due earlier, and that the Executive Board extend the period for payment of the quota increases under the 2008 Reform for Eritrea and the Syrian Arab Republic through June 30, 2022.

\footnotetext{
${ }^{8}$ See paragraph 5 in the Board of Governors Resolution No. 66-2, Fourteenth General Review of Quotas and Reform of the Executive Board.

${ }^{9}$ As of June 10, 2021, of the 186 members that had consented to their quota increases under the Fourteenth Review, 184 members had paid their quota increases. The consent and payment procedures under the $14^{\text {th }}$ General Review of Quotas do not apply to Andorra which joined the Fund on October 16, 2020.

10 See Extension of the Periods for Consent to and Payment of Quota Increase (7/17/2020).

${ }^{11}$ See Extension of the Periods for Consent to and Payment of Quota Increase (7/17/2020). 


\section{Proposed Decisions}

Accordingly, the following decisions, each of which may be adopted by a majority of the votes cast, are proposed for adoption by the Executive Board:

\section{Decision 1: Extension of the Period for Consent to Increase Quotas Under the Fourteenth General Review of Quotas}

Pursuant to paragraph 4 of the Board of Governors Resolution No. 66-2, Fourteenth General Review of Quotas and Reform of the Executive Board, the Executive Board decides that notices of consent from members to increases in their quotas must be received in the Fund by 6:00 p.m., Washington D.C. time, on June 30, 2022.

\section{Decision 2: Extension of the Period of Payment of Quota Increase Under the Fourteenth General Review of Quotas}

Pursuant to paragraph 5 of Board of the Governors Resolution No. 66-2, Fourteenth General Review of Quotas and Reform of the Executive Board, the Executive Board decides that each member shall pay to the Fund the increase in its quota under the Fourteenth General Review by the later of (a) June 30, 2022, or (b) 30 days after the date on which it notifies the Fund of its consent.

\section{Decision 3: Extension of the Period of Payment of Quota Increase Under the 2008 Reform}

Pursuant to Paragraph 4 of the Board of Governors Resolution No. 63-2, Reform of Quota and Voice in the International Monetary Fund, the Executive Board decides to extend the period for payment of quota increase by Eritrea and the Syrian Arab Republic through June 30, 2022. 